\title{
Preferred Learning Styles of Secondary Schools Students in Nairobi County, Kenya
}

\author{
Dr. Simon Sila Kaitho PhD*
}

P.O. Box 41352-00100 Nairobi, Kenya

DOI: 10.36348/JAEP.2019.v03i09.001

| Received: 12.09.2019 | Accepted: 19.09.2019 | Published: 29.09.2019

*Corresponding author: Dr. Simon Sila Kaitho

\section{Abstract}

The purpose of this study was to determine the different preferred learning styles of secondary school students in Nairobi County. The study was based on Felder Learning Style Theory and Keirsey personality learning styles theory. A purposive sample of 1,317 Form Two Students in private and public schools, 659 students were randomly selected for the study. The reliability of the treatment questionnaire in the pilot study was estimated using Pearson's Correlation method and yielded a reliability coefficient of .723 which was high enough to judge the instrument as reliable. The collected data was analysed with the aid of the Statistical Package for Social Sciences (SPSS) version 22. Data were described and summarized using percentages, and means. Univariate Analysis of Variance (ANOVA) of students' preferred learning styles showed significant differences in preference to visual and verbal learning styles in receiving of information $F(1,653)=6.42, p=.012$; in intuition and sensing learning styles in perception of information $F(1,653)=$ $9.77, p=.011$; in preference to visual and verbal categories of learning styles in receiving of information $F(1,653)=$ $6.42, p=.012$; and in preference to sequential and global learning styles in order of progressing the processing of information $F(1,653)=6.10, p=.014$. The study recommends that the ministry of education science and technology ensure facilitation is done to enable teachers to detect the learning styles to use in a different setting.

Keywords: Learning styles, Gender, preferred styles, mismatch, private and public schools.

Copyright @ 2019: This is an open-access article distributed under the terms of the Creative Commons Attribution license which permits unrestricted use, distribution, and reproduction in any medium for non-commercial use (NonCommercial, or CC-BY-NC) provided the original author and sources are credited.

\section{INTRODUCTION}

In many cases, learners are not aware of how they learn and why certain ways of learning resonate with them. Seifert [1] noted that students do not tend to reflect on the learning processes that are most productive for them. They simply learn and produce outcomes with little thought of the process itself. However, students who are aware of their learning styles easily adapt to varied teachers' instructions, which enhance performance in the sciences. This also creates self-regulated learning, which does not completely rely on the teachers' participation. Furthermore, Hendry et al. [2] have found that awareness of learning styles and choice of study strategy options are positively correlated to students' achievement. Hendry investigated how offering students different instructional options based on their learning styles positively affected learning outcomes. It was observed that such offering had a significant effect on students' overall achievement. Conversely, Gilakjani [3] examined how students cope with the experience of having to learn when their learning style does not match that of the teachers' style of teaching. Students who endure incongruent learning experiences suffer from diminished self-efficacy for tackling novel learning experiences in the future [4].

In a study in South Africa by Pather et al. [5] to determine whether students' awareness of their learning styles enhanced academic performance it was observed that students coming from the previously disadvantaged educational backgrounds were not aware of their learning styles which could otherwise empower them to understand how to adequately be prepared for tertiary learning.

\section{LITERATURE REVIEW}

In-depth research revealed three models that display what teachers should consider in their style of presentation of content to enhance the performance of students. The three models include the personality patterns model, perceptual model, and informationprocessing model.

The information processing model or cognitive styles describes learning style as the manner of 
acquiring and processing information by the brain [6]. The brain must actively generate meaning to make sense of new experience, to create the neural networks in which knowledge resides, and to organize them in ways that facilitate easy retrieval [7]. This implies that learning can be impaired if the learner perceives incongruence of the preconditions [8]. Mohsen [9] argues that successful teaching for comprehension, application, analysis, synthesis, and evaluation involves guiding the learner to generate relations among concepts and between new information and prior learning.

On the other hand, according to Keirsey [10] and Longchamp [11], personality patterns model views learning styles as personal qualities that influence a student's ability to acquire information, to interact with peers and the teachers, and otherwise participate in learning experiences. This implies that there are personalities a teacher must demonstrate and practice during the learning process to activate the innate qualities for learning to take place. In this sense, the personality model seems to articulate aspects of learning that are motivational and critically influence learning. However, a mismatch occurs in the event where teachers cannot accurately identify the preferred personality learning styles of the learners. Personality learning styles refers to distinctive behaviours, which serve as indicators of how a person learns from and adapts to his environment, and provide clues as to how a person's mind operates [12]. This implies that to match and sustain the personality learning styles of different learners in a class, teachers must develop emotional intelligence. Goleman, Boyatzis, and McKee [13] upholds that Emotional Intelligence is the capacity for recognizing our feelings and those of others, for motivating ourselves, and for managing emotions well in ourselves and in our relationships. Teachers must develop the emotional and social intelligence to teach learners with diverse personality learning styles [14]. This involves development in the aspects of Selfawareness, Self-regulation, Motivation, Empathy, and Social skills. Self-awareness is the ability to recognize and understand your moods, emotions, and drives as well as their effects on the learners. This includes paying attention to how learners influence your emotional state and having realistic self-assessment and self-deprecation sense of humour. Self-regulation is the ability to control or redirect disruptive impulses and moods. It involves the propensity to suspend judgment and think before acting to accommodate deserving learners and the development of comfort with ubiquity and openness to change and organizational commitment.

Besides, Felder and Brent [15] postulates a perceptual model and describes learning style as the way a student prefers to perceive, receive, progress and process information, which is more comprehensive and easily linked to classroom experiences. It incorporates the aspects of information processing and personal qualities that influence a student's ability to acquire information [16]. This implies there are choices the learners make to learn which can be referred to as their instructional preferred learning styles. Felder and Brent [15] classified preferred learning styles into four dimensions based on the way learners prefer to process information and convert it to knowledge, the way people preferentially perceive information, the sensory channel by which people most effectively perceive information, and how people progress to understand and master the material.

On the other hand, Wang and Mendori [17] classifies learners into four paired types of learning styles and strategies as active and reflective learners, sensing and intuitive learners, visual and verbal learners, and sequential and global learners. However, Janet [18] adds an aspect of kinaesthetic learning style a subgroup of sensing learning style. All the four-paired type of learners uses strategies, which involve memory that can be impaired by, stress experiences, which accrues due to mismatch of teaching styles to learners' preferred learning styles [19]. Active and reflective dimension deals with the way learners prefer to process information and convert it into knowledge [20]. Active learners learn by trying things out, working in a group, and discussing which is ideal for practically oriented sciences. Reflective learners learn by thinking things through and working alone [15].

Sensing/intuitive dimension deals with the way the learners tend to perceive the world either through the senses or through thinking [20]. Sensing learners are practical, oriented towards facts and procedures, and favour information arriving through their senses. They prefer getting facts and procedures using senses in knowledge acquisition to feelings. Intuitive learners are conceptual, innovative, oriented towards theories and meanings, and favour information that arises internally through memory, reflection and imagination [21]. They prefer to know something using feelings to consider the facts. Sensing perception includes a kinaesthetic learning style. The kinaesthetic learning style refers to the ability to absorb information best by experiencing, touching, doing, moving and being active in some manner [21, 15]. Preferences for tactile/kinaesthetic learners include hands-on activities (experiments, etc.), projects, and take frequent study breaks to allow movement, visual aids, role-play, and field trips [22]. Move around to learn new things (e.g. read while using an exercise bike; model in clay to learn a new concept [18].

On the other hand, intuition involves indirect perception by way of the unconscious speculation, imagination, insight, and abstraction [21, 15]. Intuitive learners like innovation, and are quick and good at grasping new concepts. They prefer principles, theories, 
welcome complications and they favor internally generated information (memory, conjecture, interpretation) [21]. Graf and Liu [23] argue that intuitive learners prefer to learn abstract material, like challenges, and are more innovative than sensing learners are. Intuitive learners are more comfortable with symbols. They read science fiction and mystery novels voraciously. Since words are symbols, translating them into what they represent comes naturally to intuitive learners [15]. Visual and Verbal dimension deals with the sensory channel the learners prefer to receive external information. Visual learners prefer pictures, diagrams, graphs, flow charts, experiments, and demonstrations, but verbal auditory learners prefer written or spoken explanations and formulae [20].

\section{METHODOLOGY}

All the schools in Nairobi County were purposively grouped into two categories private and public. Also, they were further grouped into Boys, Girls, and Mixed schools. From the list of 1,317, a sample of 659 students was randomly selected for the study using computerized random number generators, which minimized selection bias. This was achieved by using the command 'data' $>$ select cases $>$ 'random sample of cases' $>$ 'sample' $>$ 'sample size' '\% all cases. A questionnaire adapted from Felder-Silverman Model [17] designed to assess the preference of the students on four learning areas: preferred way of perceiving information-the intuitive/sensing learners, preferred processing of information- the active/reflective learners, preferred receiving Chanel of information- the visual/verbal learners and preferred progressing to understanding the global and sequential learners was used to collect data. The data collected using learning style questionnaires were analysed in General Linear Model in SPSS windows using the command 'Analyse' > 'General Linear Model'> 'Univariate or Multivariate' $>$ 'Model' $>$ 'full factorial' $>$ 'Option' $>$ 'Display descriptive statistics' > 'Observe power' $>$ 'Continue' $>$ 'Post hock' $>$ 'Tukey' $>$ 'Continue' $>$ Ok. The data was organized in terms of preferred learning styles in the perception of information, processing, preferred channel and progressing to understanding. Both Univariate and multivariate analysis of variance was done to capture the different preferred styles of learning in the perception of information, processing, receiving and progressing in understanding.

\section{RESULTS AND DATA ANALYSIS}

\section{Preferred way of perceiving information in learning}

The researcher wanted to find whether the students of private and public secondary schools in Nairobi County had different preferred styles of learning in the perception of information. Univariate analysis of variance of responses from 659 respondents done descriptive statistics (Table 1), revealed that 59.5 $\%$ (392) are sensing learners (that is they prefer to perceive information through the senses) while $40.5 \%$ (267) are intuitive learners who prefer to perceive information through thinking or internally through memory, reflection and imagination [22]. The distribution of preferences varied across gender, private, and public schools. The data indicated 58.2\% (191) of the males are sensing learners and $41.8 \%$ intuitive learners. On the other hand, $60.7 \%$ (201) of the females are sensing learners and $39.3 \%$ (130) intuitive learners. In public schools, 63.7\% (221) are sensing learners and $36.3 \%$ (126) intuitive learners. In private schools, $54.8 \%$ (171) are sensing learners and $45.2 \%$ (141) intuitive learners. In private schools $26.3 \%$ (82) having balanced, $58 \%$ (181) moderate preference for two of the dimensions and $15.7 \%$ (49) very strong preference for one of the dimensions. In public schools 25\% (87) having balanced, 59.7\% (207) moderate preference for two of the dimensions and $15.3 \%$ (53) very strong preference for one of the dimensions. In addition, of the total treatment sample 659, the data indicated $25.6 \%$ (169) had balanced preference for two of the dimensions, $58.9 \%$ (388) had moderate preference for two of the dimensions, and $15.5 \%$ (102) had very strong preference to one of the dimensions (Table 1). 
Simon Sila Kaitho; J Adv Educ Philos, Sep 2019; 3(9): 296-308

Table-1: Descriptive Statistics of Preferred Way of Perceiving Information in Learning

\begin{tabular}{|c|c|c|c|c|c|c|}
\hline Gender & School & Preferred style of Learning & $\begin{array}{l}\text { Perception } \\
\text { choice }\end{array}$ & $\mathbf{N}$ & Mean & $\begin{array}{l}\text { Std. } \\
\text { Deviation }\end{array}$ \\
\hline \multirow[t]{36}{*}{ Male } & \multirow[t]{12}{*}{ Public } & \multirow{3}{*}{$\begin{array}{l}\text { Balanced Preference for two of the } \\
\text { dimensions }\end{array}$} & Sensing & 26 & 2.3846 & 1.09825 \\
\hline & & & Intuitive & 21 & 1.9524 & 1.02353 \\
\hline & & & Total & 47 & 2.1915 & 1.07619 \\
\hline & & \multirow{3}{*}{$\begin{array}{l}\text { Moderate Preference for two of the } \\
\text { dimensions }\end{array}$} & Sensing & 72 & 3.3333 & 2.09627 \\
\hline & & & Intuitive & 36 & 3.1667 & 2.04939 \\
\hline & & & Total & 108 & 3.2778 & 2.07267 \\
\hline & & \multirow{3}{*}{$\begin{array}{l}\text { Very strong Preference for one of the } \\
\text { dimensions }\end{array}$} & Sensing & 17 & 4.5294 & 2.40098 \\
\hline & & & Intuitive & 4 & 4.0000 & 3.46410 \\
\hline & & & Total & 21 & 4.4286 & 2.54109 \\
\hline & & \multirow[t]{3}{*}{ Total } & Sensing & 115 & 3.2957 & 2.05612 \\
\hline & & & Intuitive & 61 & 2.8033 & 1.95635 \\
\hline & & & Total & 176 & 3.1250 & 2.03013 \\
\hline & \multirow[t]{12}{*}{ Private } & \multirow{3}{*}{$\begin{array}{l}\text { Balanced Preference for two of the } \\
\text { dimensions }\end{array}$} & Sensing & 16 & 1.8750 & 1.02470 \\
\hline & & & Intuitive & 25 & 2.4400 & .91652 \\
\hline & & & Total & 41 & 2.2195 & .98773 \\
\hline & & \multirow{3}{*}{$\begin{array}{l}\text { Moderate Preference for two of the } \\
\text { dimensions }\end{array}$} & Sensing & 47 & 3.6383 & 1.91590 \\
\hline & & & Intuitive & 37 & 3.5405 & 1.98038 \\
\hline & & & Total & 84 & 3.5952 & 1.93334 \\
\hline & & \multirow{3}{*}{$\begin{array}{l}\text { Very strong Preference for one of the } \\
\text { dimensions }\end{array}$} & Sensing & 13 & 6.3846 & 3.30501 \\
\hline & & & Intuitive & 14 & 5.4286 & 2.84779 \\
\hline & & & Total & 27 & 5.8889 & 3.05505 \\
\hline & & \multirow[t]{3}{*}{ Total } & Sensing & 76 & 3.7368 & 2.48391 \\
\hline & & & Intuitive & 76 & 3.5263 & 2.15081 \\
\hline & & & Total & 152 & 3.6316 & 2.31804 \\
\hline & \multirow[t]{12}{*}{ Total } & \multirow{3}{*}{$\begin{array}{l}\text { Balanced Preference for two of the } \\
\text { dimensions }\end{array}$} & Sensing & 42 & 2.1905 & 1.08736 \\
\hline & & & Intuitive & 46 & 2.2174 & .98687 \\
\hline & & & Total & 88 & 2.2045 & 1.03011 \\
\hline & & \multirow{3}{*}{$\begin{array}{l}\text { Moderate Preference for two of the } \\
\text { dimensions }\end{array}$} & Sensing & 119 & 3.4538 & 2.02421 \\
\hline & & & Intuitive & 73 & 3.3562 & 2.00949 \\
\hline & & & Total & 192 & 3.4167 & 2.01391 \\
\hline & & \multirow{3}{*}{$\begin{array}{l}\text { Very strong Preference for one of the } \\
\text { dimensions }\end{array}$} & Sensing & 30 & 5.3333 & 2.92826 \\
\hline & & & Intuitive & 18 & 5.1111 & 2.94836 \\
\hline & & & Total & 48 & 5.2500 & 2.90634 \\
\hline & & Total & Sensing & 191 & 3.4712 & 2.24029 \\
\hline & & & Intuitive & 137 & 3.2044 & 2.09038 \\
\hline & & & Total & 328 & 3.3598 & 2.17966 \\
\hline Female & Public & Balanced Preference for two of the & Sensing & 24 & 2.5833 & 1.66594 \\
\hline & & dimensions & Intuitive & 16 & 2.7500 & 1.00000 \\
\hline & & & Total & 40 & 2.6500 & 1.42415 \\
\hline & & Moderate Preference for two of the & Sensing & 63 & 4.3651 & 2.20923 \\
\hline & & dimensions & Intuitive & 36 & 4.4444 & 2.00634 \\
\hline & & & Total & 99 & 4.3939 & 2.12765 \\
\hline & & Very strong Preference for one of the & Sensing & 19 & 7.2105 & 2.97357 \\
\hline & & dimensions & Intuitive & 13 & 7.6154 & 2.36426 \\
\hline & & & Total & 32 & 7.3750 & 2.70901 \\
\hline & & Total & Sensing & 106 & 4.4717 & 2.68047 \\
\hline & & & Intuitive & 65 & 4.6615 & 2.48921 \\
\hline & & & Total & 171 & 4.5439 & 2.60364 \\
\hline & Private & Balanced Preference for two of the & Sensing & 27 & 2.4074 & 1.21716 \\
\hline & & dimensions & Intuitive & 14 & 2.7143 & 1.54066 \\
\hline & & & Total & 41 & 2.5122 & 1.32518 \\
\hline & & Moderate Preference for two of the & Sensing & 58 & 2.9310 & 1.79534 \\
\hline & & dimensions & Intuitive & 39 & 3.4103 & 1.66572 \\
\hline & & & Total & 97 & 3.1237 & 1.75153 \\
\hline & & Very strong Preference for one of the & Sensing & 10 & 5.2000 & 3.19026 \\
\hline & & dimensions & Intuitive & 12 & 5.0000 & 3.07482 \\
\hline & & & Total & 22 & 5.0909 & 3.05363 \\
\hline & & Total & Sensing & 95 & 3.0211 & 1.98922 \\
\hline & & & Intuitive & 65 & 3.5538 & 2.07689 \\
\hline & & & Total & 160 & 3.2375 & 2.03580 \\
\hline & Total & Balanced Preference for two of the & Sensing & 51 & 2.4902 & 1.43349 \\
\hline
\end{tabular}


Simon Sila Kaitho; J Adv Educ Philos, Sep 2019; 3(9): 296-308

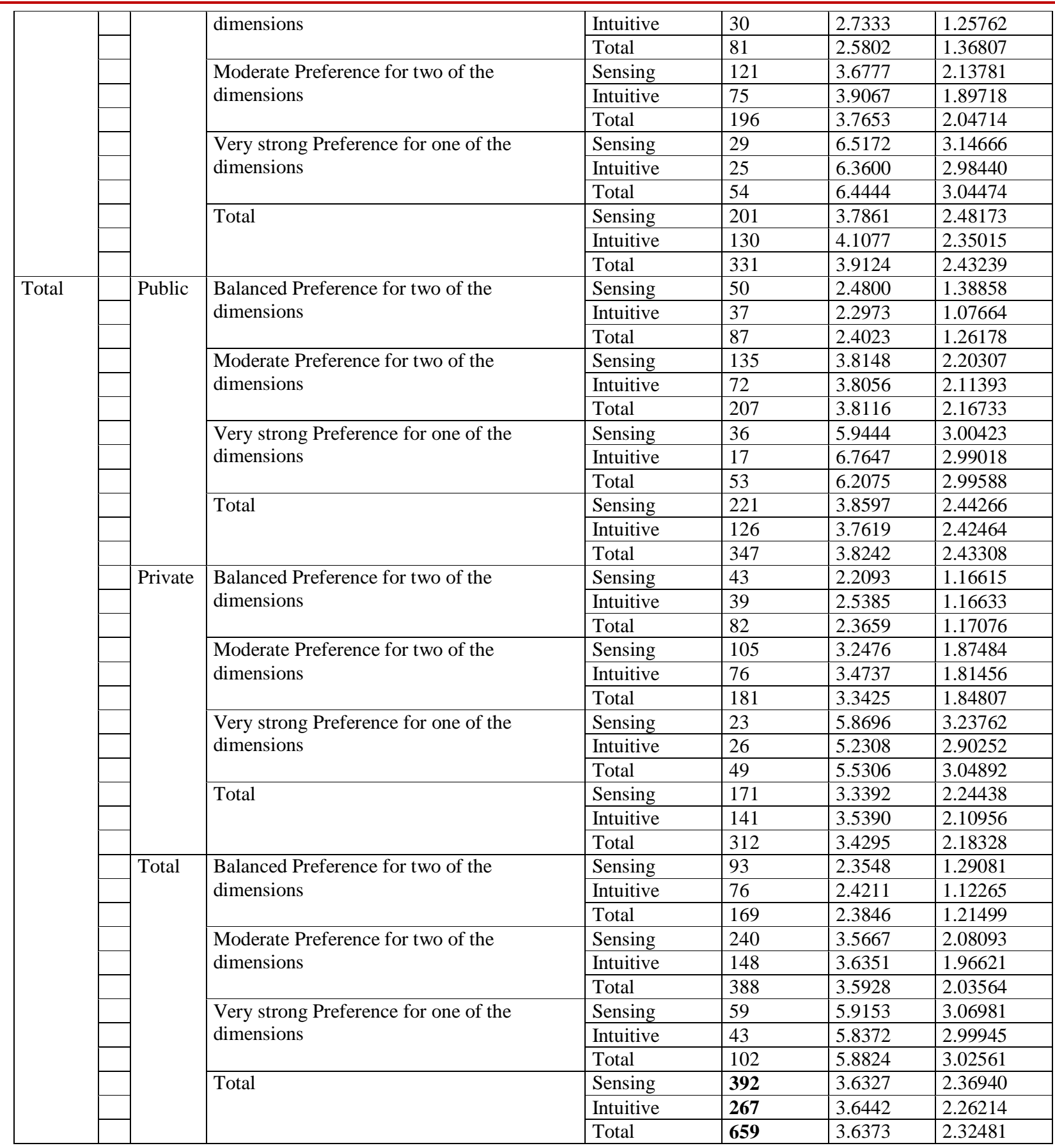

The results of Univariate Analysis of Variance (ANOVA) of tests of between-subjects effects on preferred learning style on perception of information (Table 2) showed that the preference of intuition and sense in the perception of information was not equally distributed in the schools and gender. An analysis of variance showed that difference in gender preference to categories of learning styles in the perception of information was significant $F(1,653)=9.77, p=.002$. In addition, private and public schools had significant differences in preference to categories of learning styles in the perception of information $F(1,653)=9.77, p=$ .011 . 
Table-2: Tests of Between-Subjects Effects in Perception of Information

\begin{tabular}{|c|c|c|c|c|c|c|c|c|}
\hline \multicolumn{9}{|c|}{ Dependent Variable: Perception Preference } \\
\hline Source & $\begin{array}{l}\text { Type III Sum } \\
\text { of Squares }\end{array}$ & df & $\begin{array}{l}\text { Mean } \\
\text { Square }\end{array}$ & $\mathbf{F}$ & Sig. & $\begin{array}{l}\text { Partial Eta } \\
\text { Squared }\end{array}$ & $\begin{array}{l}\text { Noncent. } \\
\text { Parameter }\end{array}$ & $\begin{array}{l}\text { Observed } \\
\text { Power }^{\text {b }}\end{array}$ \\
\hline $\begin{array}{l}\text { Corrected } \\
\text { Model }\end{array}$ & $846.654^{\mathrm{a}}$ & 5 & 169.331 & 40.807 & .000 & .238 & 204.034 & 1.000 \\
\hline Intercept & 7508.157 & 1 & 7508.157 & 1809.383 & .000 & .735 & 1809.383 & 1.000 \\
\hline Gender & 40.557 & 1 & 40.557 & 9.774 & .002 & .015 & 9.774 & .877 \\
\hline School & 27.166 & 1 & 27.166 & 6.547 & .011 & .010 & 6.547 & .724 \\
\hline $\begin{array}{l}\text { Preferred } \\
\text { styles }\end{array}$ & 768.635 & 2 & 384.317 & 92.616 & .000 & .221 & 185.233 & 1.000 \\
\hline $\begin{array}{l}\text { Perception } \\
\text { choice }\end{array}$ & 1.401 & 1 & 1.401 & .338 & .561 & .001 & .338 & .089 \\
\hline Error & 2709.668 & 653 & 4.150 & & & & & \\
\hline Total & 12275.000 & 659 & & & & & & \\
\hline $\begin{array}{l}\text { Corrected } \\
\text { Total }\end{array}$ & 3556.322 & 658 & & & & & & \\
\hline \multicolumn{9}{|c|}{ a. $\mathrm{R}$ Squared $=.238($ Adjusted R Squared $=.232)$} \\
\hline & alpha $=.05$ & & & & & & & \\
\hline
\end{tabular}

Post hoc analyses, (Table 3), indicate that in perception of information, learners with balanced preference for two dimensions of learning styles (intuitive and sensing) had significantly lower mean scores $(\mathrm{M}=2.38, \mathrm{SD}=1.21, p=.000)$ compared to individuals with moderate preference $(\mathrm{M}=3.59, \mathrm{SD}=$ 2.04) and very strong preference for a particular dimension of learning style $(\mathrm{M}=5.88, \mathrm{SD}=3.03)$. In addition, learners with very strong preference for a particular dimension of learning style had significantly higher mean scores $(\mathrm{M}=5.88, \mathrm{SD}=3.03, p=.000)$ compared to individuals with moderate preference $(\mathrm{M}=$ $3.59, \mathrm{SD}=2.04)$ and balanced preference for two dimensions of learning styles $(\mathrm{M}=2.38, \mathrm{SD}=1.21)$. This suggests that different learners have different styles of perceiving information in the learning process.
This implies that in the teaching process teachers should present information to learners according to their perception. In every lesson teachers and instructors, should analyse the teaching content to identify the relevant practical activities for every concept and physical materials necessary for them to observe data through senses to cater to the sensing learners. At the same time allowing them to manipulate as well as present or demonstrate the skills to cater to their personality. On the other hand, the teachers should provoke the imagination of intuitive learners by challenging them to analyse, synthesize, and evaluate the concepts for them to think through how the simple concepts apply in greater life. Also, giving them adequate time to think through to fulfil their personality.

Table-3: Post Hoc Tests Preferred Style of Learning in Perception of Information Multiple Comparisons Dependent Variable: Perception Preference Intuitive /Sensing

\begin{tabular}{|c|c|c|c|c|c|c|}
\hline \multicolumn{7}{|l|}{ Tukey HSD } \\
\hline \multirow[b]{2}{*}{$\begin{array}{l}\text { (I) Preferred style of } \\
\text { Learning }\end{array}$} & \multirow[b]{2}{*}{$\begin{array}{l}\text { (J) Preferred style of } \\
\text { Learning }\end{array}$} & \multirow[b]{2}{*}{$\begin{array}{l}\text { Mean } \\
\text { Difference (I-J) }\end{array}$} & \multirow[b]{2}{*}{$\begin{array}{l}\text { Std. } \\
\text { Error }\end{array}$} & \multirow[b]{2}{*}{ Sig. } & \multicolumn{2}{|c|}{ 95\% Confidence Interval } \\
\hline & & & & & $\begin{array}{l}\text { Lower } \\
\text { Bound }\end{array}$ & $\begin{array}{l}\text { Upper } \\
\text { Bound }\end{array}$ \\
\hline \multirow[t]{2}{*}{$\begin{array}{l}\text { Balanced Preference for } \\
\text { two of the dimensions }\end{array}$} & $\begin{array}{l}\text { Moderate } \\
\text { Preference } \\
\text { for two of the } \\
\text { dimensions }\end{array}$ & $-1.2082^{*}$ & .18775 & .000 & -1.6492 & -.7671 \\
\hline & $\begin{array}{l}\text { Very strong Preference } \\
\text { for one of the } \\
\text { dimensions }\end{array}$ & $-3.4977^{*}$ & .25541 & .000 & -4.0977 & -2.8978 \\
\hline \multirow[t]{2}{*}{$\begin{array}{l}\text { Moderate Preference for } \\
\text { two of the dimensions }\end{array}$} & $\begin{array}{l}\text { Balanced } \\
\text { Preference } \\
\text { for two of the } \\
\text { dimensions }\end{array}$ & $1.2082^{*}$ & .18775 & .000 & .7671 & 1.6492 \\
\hline & $\begin{array}{l}\text { Very strong Preference } \\
\text { for one of the } \\
\text { dimensions }\end{array}$ & $-2.2896^{*}$ & .22666 & .000 & -2.8220 & -1.7571 \\
\hline $\begin{array}{l}\text { Very strong Preference } \\
\text { for one of the dimensions }\end{array}$ & $\begin{array}{l}\text { Balanced } \\
\text { Preference } \\
\text { for two of the } \\
\text { dimensions }\end{array}$ & $3.4977^{*}$ & .25541 & .000 & 2.8978 & 4.0977 \\
\hline
\end{tabular}


Simon Sila Kaitho; J Adv Educ Philos, Sep 2019; 3(9): 296-308

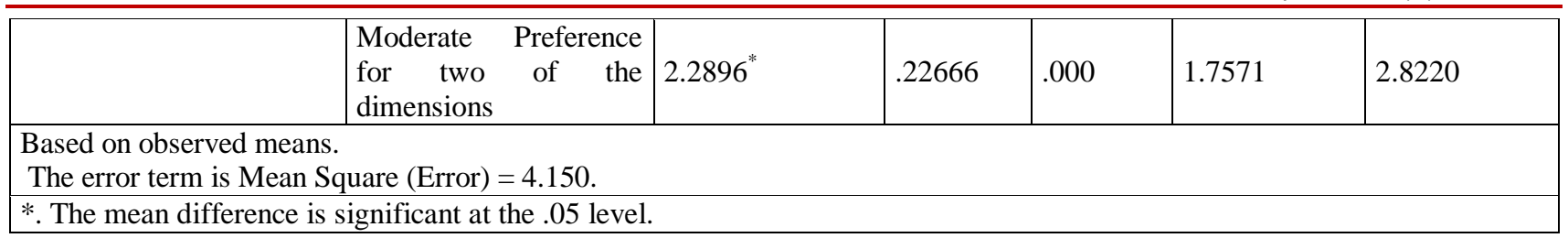

\section{Preferred by way of processing information in learning}

The researcher wanted to find whether the students of private and public secondary schools in Nairobi County had different preferred styles of processing of information. Univariate analysis of variance of responses from 659 respondents done. Descriptive statistics (Table 4), revealed that $71.5 \%$ (471) are active learners (that is they prefer to process information by trying things out, working in a group, and discussing) while $28.5 \%$ (188) are reflective learners who prefer to process information by thinking things through and working alone (Rivera, 2016). The distribution of preferences varied across gender, private, and public schools. The data indicated $71.0 \%$ (233) of the males are active learners and $29.0 \%$ (95) reflective learners. On the other hand, $71.9 \%$ (238) of the females are active learners and $28.1 \%$ (93) reflective learners. In public schools, $70.9 \%$ (246) are active learners and $29.1 \%$ (101) reflective learners. In private schools, $72.1 \%$ (225) are active learners and
$27.9 \%$ (87) reflective learners. In private schools $26.3 \%$ (82) having balanced, 58\% (181) moderate preference for two of the dimensions and $15.7 \%$ (49) very strong preference for one of the dimensions. In public schools $25 \%$ (87) having balanced, 59.7\% (207) moderate preference for two of the dimensions and $15.3 \%$ (53) very strong preference for one of the dimensions. In addition, of the total treatment sample 659 , the data indicated $25.6 \%$ (169) had balanced preference for two of the dimensions, $58.9 \%$ (388) had moderate preference for two of the dimensions, and $15.5 \%$ (102) had very strong preference to one of the dimensions.

The results of Univariate Analysis of Variance (ANOVA) of tests of between-subjects' effects on preferred learning styles on the processing of information (Table 5) showed that gender preferences to active and reflective learning styles in the processing of information were not significantly different $F(1,653)=2.65, p=.104$

Table-5: Tests of Between-Subjects Effects in Processing of Information

\begin{tabular}{|c|c|c|c|c|c|c|c|c|}
\hline \multicolumn{9}{|c|}{ Processing Preference Active/Reflective } \\
\hline Source & $\begin{array}{l}\text { Type III } \\
\text { Sum of } \\
\text { Squares }\end{array}$ & df & $\begin{array}{l}\text { Mean } \\
\text { Square }\end{array}$ & $\mathbf{F}$ & Sig. & $\begin{array}{l}\text { Partial Eta } \\
\text { Squared }\end{array}$ & $\begin{array}{l}\text { Noncent. } \\
\text { Parameter }\end{array}$ & $\begin{array}{l}\text { Observed } \\
\text { Power }^{b}\end{array}$ \\
\hline $\begin{array}{l}\text { Corrected } \\
\text { Model }\end{array}$ & $537.962^{\mathrm{a}}$ & 5 & 107.592 & 24.699 & .000 & .159 & 123.496 & 1.000 \\
\hline Intercept & 5030.601 & 1 & 5030.601 & 1154.836 & .000 & .639 & 1154.836 & 1.000 \\
\hline Gender & 11.546 & 1 & 11.546 & 2.651 & .104 & .004 & 2.651 & .369 \\
\hline School & 21.325 & 1 & 21.325 & 4.895 & .027 & .007 & 4.895 & .598 \\
\hline $\begin{array}{l}\text { Preferred } \\
\text { style }\end{array}$ & 504.318 & 2 & 252.159 & 57.886 & .000 & .151 & 115.772 & 1.000 \\
\hline $\begin{array}{l}\text { Processing } \\
\text { choice }\end{array}$ & 2.128 & 1 & 2.128 & .488 & .485 & .001 & .488 & .107 \\
\hline Error & 2844.544 & 653 & 4.356 & & & & & \\
\hline Total & 10667.000 & 659 & & & & & & \\
\hline $\begin{array}{l}\text { Corrected } \\
\text { Total }\end{array}$ & 3382.507 & 658 & & & & & & \\
\hline \multicolumn{9}{|c|}{ a. R Squared $=.159($ Adjusted R Squared $=.153)$} \\
\hline & & & & & & & & \\
\hline
\end{tabular}

However, students in private and public schools had significant differences in preference to active and reflective learning styles in the processing of information $F(1,653)=4.99, p=.027$ (Table 5). Post hoc analyses, (Tables 6), indicate that in processing of information, learners with balanced preference for two dimensions of learning styles (active and reflective) had significantly lower mean scores $(M=2.14 S D=$ $1.25, p=.000)$ compared to individuals with moderate preference $(M=3.42, S D=1.98)$ and very strong preference for a particular dimension of learning style $(M=4.92, \mathrm{SD}=3.31)$. 
Table-6: Post Hoc Tests Preferred Style of Learning of Processing Information Multiple Comparisons Dependent Variable: Processing Preference Active/Reflective

\begin{tabular}{|c|c|c|c|c|c|c|}
\hline \multicolumn{7}{|c|}{ Dependent Variable: Processing Preference Active/Reflective } \\
\hline \multicolumn{7}{|c|}{ T } \\
\hline \multirow[b]{2}{*}{$\begin{array}{l}\text { (I) Preferred style of } \\
\text { Learning }\end{array}$} & \multirow[b]{2}{*}{$\begin{array}{l}(\mathrm{J}) \text { Preferred style of } \\
\text { Learning }\end{array}$} & \multirow{2}{*}{$\begin{array}{l}\text { Mean } \\
\text { Difference } \\
\text { (I-J) }\end{array}$} & \multirow[b]{2}{*}{$\begin{array}{l}\text { Std. } \\
\text { Error }\end{array}$} & \multirow[b]{2}{*}{ Sig. } & \multicolumn{2}{|c|}{ 95\% Confidence Interva } \\
\hline & & & & & $\begin{array}{l}\text { Lower } \\
\text { Bound }\end{array}$ & $\begin{array}{l}\text { Upper } \\
\text { Bound }\end{array}$ \\
\hline \multirow[t]{2}{*}{$\begin{array}{l}\text { Balanced Preference for } \\
\text { two of the dimensions }\end{array}$} & $\begin{array}{l}\text { Moderate Preference for } \\
\text { two of the dimensions }\end{array}$ & $-1.2866^{*}$ & .19236 & .000 & -1.7385 & -.8347 \\
\hline & $\begin{array}{l}\text { Very strong Preference } \\
\text { for one of the } \\
\text { dimensions }\end{array}$ & $-2.7855^{*}$ & .26169 & .000 & -3.4002 & -2.1707 \\
\hline \multirow[t]{2}{*}{$\begin{array}{l}\text { Moderate Preference for } \\
\text { two of the dimensions }\end{array}$} & $\begin{array}{l}\text { Balanced Preference for } \\
\text { two of the dimensions }\end{array}$ & $1.2866^{*}$ & .19236 & .000 & .8347 & 1.7385 \\
\hline & $\begin{array}{l}\text { Very strong Preference } \\
\text { for one of the } \\
\text { dimensions }\end{array}$ & $-1.4989^{*}$ & .23224 & .000 & -2.0444 & -.9533 \\
\hline \multirow{2}{*}{$\begin{array}{l}\text { Very strong } \text { Preference } \\
\text { for one of the } \\
\text { dimensions }\end{array}$} & $\begin{array}{l}\text { Balanced Preference for } \\
\text { two of the dimensions }\end{array}$ & $2.7855^{*}$ & .26169 & .000 & 2.1707 & 3.4002 \\
\hline & \begin{tabular}{|l|} 
Moderate Preference for \\
two of the dimensions
\end{tabular} & $1.4989^{*}$ & .23224 & .000 & .9533 & 2.0444 \\
\hline
\end{tabular}

In addition, learners with very strong preference for a particular dimension of learning style had significantly higher mean scores $(M=4.92, \mathrm{SD}=$ $3.31, p<.000)$ compared to individuals with moderate preference $(M=3.42, S D=1.98)$ and balanced preference for two dimensions of learning styles $(M=$ $2.14 S D=1.25)$.

This suggests that different learners have different styles of processing scientific information in the learning process. This implies that in the teaching process teachers should facilitate the conversion of information into knowledge by making active learners process the information through trying/doing experiments, observing, and recording. Besides, allowing the students to manipulate the variables by doing something physical with presented material like calculations of dimensions to realize their personality. On the other hand, the teachers should assist reflective learners to convert information into knowledge by making them give reasons for the observations / justify information observed. Also, according to the time to think before acting and to assimilate before commenting or demonstrating the concepts to appreciate their personality.

These finding supports Alavi and Toozandehjani [24], that most people have a preference to identifiable method of interacting with, taking in, and processing information. Besides, the study agrees with the findings of Kaushik [25] in his study that attempts to bridge David Kolb's theory of Learning Styles with Gardner's Theory of Multiple Intelligences to overcome criticisms to both that different learner have a preferred way of thinking, processing, and understanding information. This further implies that understanding the student's level, developmental stage and preferred style of processing information help the instructors choose the best teaching style to achieve the negotiated goals.

\section{Preferred Styles of Receiving Information in Learning}

The researcher wanted to find whether the students of private and public secondary schools in Nairobi County had different preferred channels of receiving information. Univariate analysis of variance of responses from 659 respondents done descriptive statistics (Table 7) revealed that $53.0 \%$ (349) are visual learners (that is they prefer to use sight as the sensory channel to receive external information) while $47.0 \%$ (310) are verbal learners who prefer to hear external information in the process of learning.

The distribution of preferences varied across gender, private, and public schools. The data indicated $51.8 \%$ (170) of the males are visual learners and $48.2 \%$ (158) verbal learners. On the other hand, 54.1\% (179) of the females are visual learners and $45.9 \%(152)$ 
verbal learners. In public schools, 55.3\% (192) are visual learners and $44.7 \%$ (155) verbal learners. In private schools, $50.3 \%$ (157) are visual learners and $49.7 \%$ (155) verbal learners. In private schools $26.3 \%$ (82) having balanced, $58 \%$ (181) moderate preference for two of the dimensions and $15.7 \%$ (49) very strong preference for one of the dimensions. In public schools $25 \%$ (87) having balanced, 59.7\% (207) moderate preference for two of the dimensions and $15.3 \%$ (53) very strong preference for one of the dimensions. In addition, of the total treatment sample 659 , the data indicated $25.6 \%$ (169) had balanced preference for two of the dimensions, $58.9 \%$ (388) had moderate preference for two of the dimensions, and $15.5 \%$ (102) had very strong preference to one of the dimensions.

The results of Univariate Analysis of Variance (ANOVA) of tests of between-subjects effects on preferred learning styles of receiving of information (Table 8) showed that gender preferences to visual and verbal learning styles in receiving of information were not significantly different $F(1,653)=3.15, p=.077$

Table-8: Tests of Between-Subjects Effects in Preference of Receiving information

\begin{tabular}{|l|l|l|l|l|l|l|l|l|l|}
\hline \multicolumn{7}{|c|}{ Dependent Variable: } & Receiving Preference Visual/Verbal \\
\hline Source & $\begin{array}{l}\text { Type III Sum of } \\
\text { Squares }\end{array}$ & df & $\begin{array}{l}\text { Mean } \\
\text { Square }\end{array}$ & F & Sig. & $\begin{array}{l}\text { Partial } \\
\text { Squared }\end{array}$ & $\begin{array}{l}\text { Etancent. } \\
\text { Parameter }\end{array}$ & $\begin{array}{l}\text { Observed } \\
\text { Power }\end{array}$ \\
\hline $\begin{array}{l}\text { Corrected } \\
\text { Model }\end{array}$ & $261.674^{\mathrm{a}}$ & 5 & 52.335 & 13.379 & .000 & .093 & 66.894 & 1.000 \\
\hline Intercept & 3550.574 & 1 & 3550.574 & 907.668 & .000 & .582 & 907.668 & 1.000 \\
\hline Gender & 12.310 & 1 & 12.310 & 3.147 & .077 & .005 & 3.147 & .425 \\
\hline School & 25.097 & 1 & 25.097 & 6.416 & .012 & .010 & 6.416 & .715 \\
\hline $\begin{array}{l}\text { Preferred } \\
\text { style }\end{array}$ & 220.819 & 2 & 110.409 & 28.225 & .000 & .080 & 56.450 & 1.000 \\
\hline $\begin{array}{l}\text { Receiving } \\
\text { choice }\end{array}$ & 1.413 & 1 & 1.413 & .361 & .548 & .001 & .361 & .092 \\
\hline Error & 2554.375 & 653 & 3.912 & & & & & & \\
\hline Total & 7043.000 & 659 & & & & & & & \\
\hline $\begin{array}{l}\text { Corrected } \\
\text { Total }\end{array}$ & 2816.049 & 658 & & & & & \\
\hline a. R Squared
\end{tabular}

However, students in private and public schools had significant differences in preference to visual and verbal learning styles in receiving information $F(1,653)=6.42, p=.012$ (Table 8). Post hoc analyses, (Tables 9), indicate that in receiving of information, learners with balanced preference for two dimensions of learning styles (visual and verbal) had significantly lower mean scores $(M=1.82 S D=$ $1.03, p=.000)$ compared to individuals with moderate preference $(M=2.42, S D=1.91)$ and very strong preference for a particular dimension of learning style $(M=3.69, \mathrm{SD}=3.15)$.

Table-9: Post Hoc Tests Preferred Style of Learning in Receiving of Information Multiple Comparisons. Dependent Variable: Receiving Visual/Verbal

\begin{tabular}{|c|c|c|c|c|c|c|}
\hline \multicolumn{7}{|c|}{ Tukey HSD } \\
\hline \multirow[b]{2}{*}{$\begin{array}{l}\text { (I) Preferred style of } \\
\text { Learning }\end{array}$} & \multirow[b]{2}{*}{$\begin{array}{l}\text { (J) Preferred style of } \\
\text { Learning }\end{array}$} & \multirow{2}{*}{$\begin{array}{l}\text { Mean } \\
\text { Difference } \\
\text { (I-J) }\end{array}$} & \multirow[b]{2}{*}{$\begin{array}{l}\text { Std. } \\
\text { Error }\end{array}$} & \multirow[b]{2}{*}{ Sig. } & \multicolumn{2}{|c|}{ 95\% Confidence Interval } \\
\hline & & & & & $\begin{array}{l}\text { Lower } \\
\text { Bound }\end{array}$ & $\begin{array}{l}\text { Upper } \\
\text { Bound }\end{array}$ \\
\hline \multirow[t]{2}{*}{$\begin{array}{l}\text { Balanced Preference for } \\
\text { two of the dimensions }\end{array}$} & $\begin{array}{l}\text { Moderate Preference for } \\
\text { two of the dimensions }\end{array}$ & $-.7247^{*}$ & .18229 & .000 & -1.1529 & -.2965 \\
\hline & $\begin{array}{l}\text { Very strong Preference } \\
\text { for one of the } \\
\text { dimensions }\end{array}$ & $-1.8697^{*}$ & .24799 & .000 & -2.4522 & -1.2872 \\
\hline \multirow[t]{2}{*}{$\begin{array}{l}\text { Moderate Preference for } \\
\text { two of the dimensions }\end{array}$} & $\begin{array}{l}\text { Balanced Preference for } \\
\text { two of the dimensions }\end{array}$ & $.7247^{*}$ & .18229 & .000 & .2965 & 1.1529 \\
\hline & $\begin{array}{l}\text { Very strong Preference } \\
\text { for one of the } \\
\text { dimensions }\end{array}$ & $-1.1450^{*}$ & .22007 & .000 & -1.6620 & -.6281 \\
\hline \multirow{2}{*}{$\begin{array}{l}\text { Very strong } \\
\text { for oference } \\
\text { dimensions }\end{array}$} & $\begin{array}{l}\text { Balanced Preference for } \\
\text { two of the dimensions }\end{array}$ & $1.8697^{*}$ & .24799 & .000 & 1.2872 & 2.4522 \\
\hline & $\begin{array}{l}\text { Moderate Preference for } \\
\text { two of the dimensions }\end{array}$ & $1.1450^{*}$ & .22007 & .000 & .6281 & 1.6620 \\
\hline
\end{tabular}


Based on observed means.

The error term is Mean Square (Error) = 3.912.

*. The mean difference is significant at the .05 level.

In addition, learners with very strong preference for a particular dimension of learning style had significantly higher mean scores $(M=3.69, \mathrm{SD}=$ $3.15, p=.000)$ compared to individuals with moderate preference $(M=2.42, S D=1.91)$ and balanced preference for two dimensions of learning styles $(M=$ $1.82 S D=1.03)$. This suggests that different learners have different preferred styles/channels of receiving of scientific information in the learning process. This implies that in teaching process teachers should use the channel the learners prefer by presenting information in form of pictures, diagrams, graphs, flow charts, experiments, demonstrations, using legible writing on instructional boards as well encouraging the visual learners to write legibly in their notebooks because they remember best what they have seen. Besides, proper lighting of the study rooms should be ensured to make them see clearly to satisfy their personalities. On the other hand speaking clearly, explaining points and processes clearly at their pace and clarifying written assignments verbally help the verbal learners. In addition, making sure, they have the opportunity to speak and express their opinion in discussions to fulfil their personality.

\section{Preferred Order of the Processing of Information in Learning}

The researcher wanted to find whether the students of private and public secondary schools in Nairobi County had a different preferred order of progressing the processing of information into knowledge in learning. Univariate analysis of variance of responses from 659 respondents done descriptive statistics (Table 10) revealed that $73.7 \%$ (486) are sequential learners (that is they prefer to gain understanding linearly, with each new piece of information building logically from previous pieces) while $26.3 \%$ (173) are global learners who absorb information almost randomly, in no apparent logical sequence. The distribution of preferences varied across gender, private, and public schools. The data indicated $72.0 \%$ (236) of the males are sequential learners and $28.0 \%$ (92) global learners. On the other hand, $75.5 \%$ (250) of the females are sequential learners and $24.5 \%$ (81) global learners. In public schools, $72.6 \%$ (252) are sequential learners and $27.4 \%$ (95) global learners. In private schools, $75.0 \%$ (252) are sequential learners and $25.0 \%$ (78) global learners. In private schools $26.3 \%$ (82) having balanced, 58\% (181) moderate preference for two of the dimensions and $15.7 \%$ (49) very strong preference for one of the dimensions. In public schools 25\% (87) having balanced, 59.7\% (207) moderate preference for two of the dimensions and $15.3 \%$ (53) very strong preference for one of the dimensions. Besides, of the total treatment sample 659 the data indicated $25.6 \%$ (169) had a balanced preference for two of the dimensions, $58.9 \%$ (388) had a moderate preference for two of the dimensions, and $15.5 \%$ (102) had very strong preference to one of the dimensions.

The results of Univariate Analysis of Variance (ANOVA) of tests of between-subjects effects on preferred learning styles on order of progressing the processing of information (Table 10) showed that gender preferences to sequencing and global learning styles in the order of progressing the processing of information were significantly different $F(1,653)=$ $4.53, p=.034$

Table-11: Tests of Between-Subjects Effects of Preferred Order of Progressing the Processing of Information Dependent Variable: Progressing Preference Sequencing / Global Learning

\begin{tabular}{|c|c|c|c|c|c|c|c|c|}
\hline Source & \begin{tabular}{lr|} 
Type & III \\
Sum & of \\
Squares & \\
\end{tabular} & df & $\begin{array}{l}\text { Mean } \\
\text { Square }\end{array}$ & $\mathbf{F}$ & Sig. & $\begin{array}{l}\text { Partial Eta } \\
\text { Squared }\end{array}$ & $\begin{array}{l}\text { Noncent. } \\
\text { Parameter }\end{array}$ & $\begin{array}{l}\text { Observed } \\
\text { Power }^{b}\end{array}$ \\
\hline $\begin{array}{l}\text { Corrected } \\
\text { Model }\end{array}$ & $315.434^{\mathrm{a}}$ & 5 & 63.087 & 15.066 & .000 & .103 & 75.329 & 1.000 \\
\hline Intercept & 3895.464 & 1 & 3895.464 & 930.282 & .000 & .588 & 930.282 & 1.000 \\
\hline Gender & 18.971 & 1 & 18.971 & 4.531 & .034 & .007 & 4.531 & .566 \\
\hline School & 25.544 & 1 & 25.544 & 6.100 & .014 & .009 & 6.100 & .694 \\
\hline Preferred style & 266.242 & 2 & 133.121 & 31.791 & .000 & .089 & 63.582 & 1.000 \\
\hline $\begin{array}{l}\text { Progressing } \\
\text { choice }\end{array}$ & 2.881 & 1 & 2.881 & .688 & .407 & .001 & .688 & .132 \\
\hline Error & 2734.374 & 653 & 4.187 & & & & & \\
\hline Total & 8755.000 & 659 & & & & & & \\
\hline $\begin{array}{l}\text { Corrected } \\
\text { Total }\end{array}$ & 3049.809 & 658 & & & & & & \\
\hline \multicolumn{9}{|c|}{ a. $\mathrm{R}$ Squared $=.103($ Adjusted R Squared $=.097)$} \\
\hline
\end{tabular}


Also, students in private and public schools' students had significant differences in preference to sequential and global learning styles in order of progressing the processing of information $F(1,653)=$ $6.10, p=.014$ (Table 11).
Post hoc analyses, (Table 12), indicate that in preferred order of progressing the processing of information, learners with balanced preference for two dimensions of learning styles (sequential and global) had significantly lower mean scores $(\mathrm{M}=1.82 \mathrm{SD}=$ $1.03, \mathrm{p}=.000)$ compared to individuals with moderate preference $(\mathrm{M}=2.42, \quad \mathrm{SD}=1.91)$.

Table-12: Post Hoc Tests Preferred Style of Learning of Preferred Order of Progressing the Processing of Information Multiple Comparisons

\begin{tabular}{|c|c|c|c|c|c|c|}
\hline \multicolumn{7}{|c|}{ Dependent Variable: Progressing Preference Sequencing / Global Learning } \\
\hline \multicolumn{7}{|l|}{ Tukey HSD } \\
\hline \multirow[b]{2}{*}{$\begin{array}{l}\text { (I) Preferred style of } \\
\text { Learning }\end{array}$} & \multirow[b]{2}{*}{$\begin{array}{l}\text { (J) Preferred style of } \\
\text { Learning }\end{array}$} & \multirow{2}{*}{$\begin{array}{l}\text { Mean } \\
\text { Difference } \\
\text { (I-J) }\end{array}$} & \multirow[b]{2}{*}{$\begin{array}{l}\text { Std. } \\
\text { Error }\end{array}$} & \multirow[b]{2}{*}{ Sig. } & \multicolumn{2}{|c|}{ 95\% Confidence Interva } \\
\hline & & & & & $\begin{array}{l}\text { Lower } \\
\text { Bound }\end{array}$ & $\begin{array}{l}\text { Upper } \\
\text { Bound }\end{array}$ \\
\hline \multirow[t]{2}{*}{$\begin{array}{l}\text { Balanced Preference for } \\
\text { two of the dimensions }\end{array}$} & $\begin{array}{l}\text { Moderate Preference for } \\
\text { two of the dimensions }\end{array}$ & $-1.0220^{*}$ & .18860 & .000 & -1.4650 & -.5789 \\
\hline & $\begin{array}{l}\text { Very strong Preference } \\
\text { for one of the } \\
\text { dimensions }\end{array}$ & $-2.0096^{*}$ & .25657 & .000 & -2.6123 & -1.4069 \\
\hline \multirow[t]{2}{*}{$\begin{array}{l}\text { Moderate Preference for } \\
\text { two of the dimensions }\end{array}$} & $\begin{array}{l}\text { Balanced Preference for } \\
\text { two of the dimensions }\end{array}$ & $1.0220^{*}$ & .18860 & .000 & .5789 & 1.4650 \\
\hline & $\begin{array}{l}\text { Very strong Preference } \\
\text { for one of the } \\
\text { dimensions }\end{array}$ & $-.9877^{*}$ & .22770 & .000 & -1.5225 & -.4528 \\
\hline \multirow{2}{*}{$\begin{array}{l}\text { Very strong Preference } \\
\text { for one of the } \\
\text { dimensions }\end{array}$} & $\begin{array}{l}\text { Balanced Preference for } \\
\text { two of the dimensions }\end{array}$ & $2.0096^{*}$ & .25657 & .000 & 1.4069 & 2.6123 \\
\hline & $\begin{array}{l}\text { Moderate Preference for } \\
\text { two of the dimensions }\end{array}$ & $.9877^{*}$ & .22770 & .000 & .4528 & 1.5225 \\
\hline
\end{tabular}

In addition, learners with very strong preference for a particular dimension of learning style had significantly higher mean scores $(M=3.69, \mathrm{SD}=$ $3.15, p=.000)$ compared to individuals with moderate preference $(M=2.42, S D=1.91)$ and balanced preference for two dimensions (sequential and global) of learning styles $(M=1.82 S D=1.03)$.

This suggests that different learners have a different preferred order of progressing the processing of scientific information in the learning process. This implies that in teaching process teachers should order the style of presentation and development of lessons towards the understanding of global learners who are holistic, systems thinkers and learn in large leaps by giving an outline of every concept and sub-topic. Also, being friendly and patient in helping them slowly discover how the concepts assist and relate to their life to uphold their personality. On the hand developed the understanding of the sequential learners who gain understanding in a linear orderly fashion by moving step-by-step in every point, analysing the concepts by giving their similarities and differences, insisting they write the points and summarise the concepts. Besides, moving at their pace to enhance their personality.

This study supports several studies Mona and Clas [26] and Gaikwad [27] that different students have different preferred styles of order of progressing the assimilation of information, further that teachers in secondary schools must consider both the structure of the content, and the order different students prefer to assimilate the content as new knowledge.

The global learners need to grasp the big picture before they have any chance to understand the details of the subject. However, if there is no picture it may difficult for them to study. They may feel stupid 
Simon Sila Kaitho; J Adv Educ Philos, Sep 2019; 3(9): 296-308

when they are struggling to master material with which most of their contemporaries seem to have little trouble. Some eventually become discouraged with education and drop out if there is no proper support school system [28]. On the other hand, Narayani further observed that the mean value of the academic achievement of sequential learners is greater than the mean value of the academic achievement of global learners. They learn in a logical progression and small incremental steps. Generally, they have more learning success because the majority of books and teaching strategies used by schoolteachers are sequential [28].

\section{CONCLUSION}

The findings of this study demonstrates and supports Wouter and Katrien [29] that assessment of concept learning styles needed a more appropriate articulation of the discourse to help reduce misunderstandings in the preference of learning styles. Past research work held that the assumption that people can be clustered in different groups is not supported by empirical evidence [24, 29]. The clustering contributed to the misunderstandings. This study demonstrates that all learners display specific preferred learning styles in the perception of information, processing information, preferred channel of receiving information and order of progressing the processing information rather than possessing only one of the learning styles. Univariate Analysis of Variance (ANOVA) of students' preferred learning styles showed significant differences in preference to visual and verbal learning styles in receiving of information $F(1,653)=6.42, p=.012$; in intuition and sensing learning styles in perception of information $F(1,653)=9.77, p=.011$; in preference to visual and verbal categories of learning styles in receiving of information $F(1,653)=6.42, p=.012$; and in preference to sequential and global learning styles in order of progressing the processing of information $F(1,653)=6.10, p=.014$.

Besides, there were significant differences in gender preference to intuitive and sensing of learning styles in the perception of information $F(1,653)=$ $9.77, p=.002$. In addition, in preferences to sequencing and global categories learning styles in the order of progressing the processing of information $F(1,653)=$ $4.53, p=.034$. On the other hand, gender preferences showed no significant differences to active and reflective learning styles in processing of information $F(1,653)=2.65, p=.104$ and to visual and verbal learning styles in receiving of information $F(1,653)=3.15, p=.077$.

\section{REFERENCES}

1. Seifert, H. E. (2016). Gender differences, learning styles, and participation in higher mathematics (Doctoral thesis) Walden University.

2. Hendry, G. D., Heinrich, P., Lyon, P. M., Barratt, A. L., Simpson, J. M., Hyde, S. J., Gonsalkorale, S., Hyde, M., \& Mgaieth, S. (2005). Helping students understand their learning styles: Effects on study self-efficacy, preference for group work, and group climate. Educational Psychology, 25(4), 395-407.

3. Gilakjani, A. P. (2012). A match or mismatch between learning styles of the learners and teaching styles of the teachers. International Journal of Modern Education and Computer Science, 11, 5160.

4. Luedtke, T. (2016). Undergraduate nursing student perceptions of developing confidence through clinical learning experiences. (Master's Thesis), University of Manitoba Winnipeg. Retrieved from https://mspace.lib.umanitoba.ca/bitstream/han dle/1993/31824/luedtke_tracy.pdf?sequence=3

5. Pather, S., Norodien-Fataar, N., Cupido, X., \& Mkonto, N. (2017). First year students' experience of access and engagement at a University of Technology. Journal of Education (University of KwaZulu-Natal), 69, 161-184.

6. Lusweti, S., Kwena, J., \& Mondoh, H. (2018). Predictive power of cognitive styles on academic performance of students in selected national secondary schools in Kenya. Retrieved from https://www.cogentoa.com/article/10.1080/233119 08.2018.1444908.pdf

7. Gee, K. L. (2011). The impact of instructorprovided lecture notes and learning interventions on student note taking and generative processing. (Master's Thesis), San José State University). Retrieved from http://scholarworks.sjsu.edu/cgi/viewcontent.cgi?ar ticle $=4925 \&$ context $=$ etd_theses

8. Daemi, M. N., Tahriri, A., \& Zafarghandi, A. M. (2017). The relationship between classroom environment and EFL Learners' academic selfefficacy. International Journal of Education \& Literacy Studies.

9. Mohsen, E. (2017). Harmonizing Teaching Tools with Cognitive Learning Outcomes in the Teaching of Economics. International Journal of Economics and Finance, 9(1)

10. Keirsey, D. (2013). Keirsey types and learning styles. $\quad$ Retrieve from http://iws.collin.edu/mbrooks/learning_styles/keirs ey_types.pdf

11. Longchamp, J. C. (2017). The effect of student learning objectives on teachers and teaching as part of the teacher evaluation process: A grounded theory study. Graduate College Dissertations and Theses.

734.

http://scholarworks.uvm.edu/graddis/734

12. Al-Sarem, M., Bellafkih, M., \& Ramdani, M. (2014). Adaptation patterns with respect to learning styles. Conference Paper - May 2014. Retrieved on 20/4/2017 from https://www.researchgate.net/profile/M_Bellafkih/ publication/264323008_Adaptation_Patterns_with_ respect_to_Learning_Styles/links/53d8d95f0cf2e38 
c6331b255/Adaptation-Patterns-with-respect-toLearning-Styles.pdf.

13. Goleman, D., Boyatzis, R., \& McKee, A. (2002). Primal leadership: Realizing the importance of emotional intelligence. Harvard Business School Press. Retrieved from https://ohio4h.org/sites/ohio4h/files/imce/Emotiona 1\%20Intelligence\%20Background.pdf

14. Walter, O., \& Marcel, A. (2013). Emotional intelligence and teaching self-efficacy as predictors of teaching ability. Journal of Studies in Education, 3(3) Retrieved from http://macrothink.org/journal/index.php/jse/article/ download/3785/3305

15. Felder, R. M., \& Brent, R. (2017). Effective teaching: A workshop. Department of Chemical \& Biomolecular Engineering North Carolina State University. Retrieved from https://engineering.purdue.edu/Engr/AboutUs/Adm inistration/AcademicAffairs/Resources/Teaching/ef fective-teaching.pdf.

16. Odendaal, A. (2013). Perceptual learning style as an influence on the practising of instrument students in higher music education. (Doctoral thesis), Sibelius Academy of the University of the Arts, Helsinki. Retrieved from http://ethesis.siba.fi/files/odendaal_thesis_web.pdf

17. Wang, J., \& Mendori, T. (2015). The reliability and validity of Felder- Silverman index of learning styles in Mandarin Version. Information Engineering Express International Institute of Applied Informatics, 1(3), 1-8.

18. Janet.(2008). Understanding Your Learning Styles. Ldpride.net Retrieved from http://www.ldpride.net/Understanding-LearningStyles.pdfv

19. Souza-Talarico, J. N., Marin, M., Sindi, S., \& Lupien, S. J. (2011). Effects of stress hormones on the brain and cognition: Evidence from normal to pathological aging. Dement Neuropsychol, 5(1), 816.

20. Zywno, M. S., \& Waalen, J. K.. (2012). The effect of individual learning styles on student outcomes in technology-enabled education. Global Journal of Engineering. Education, 6(1) Retrieved from http://www.wiete.com.au/journals/GJEE/Publish/v ol6no1/Zywno.pdf
21. Awla, H. A. (2014). Learning styles and their relation to teaching styles. International Journal of Language and Linguistics 2014, 2(3), 241-245.

22. Sprenger, M. (2017). Differentiation through learning styles and memory. Thousand Oaks, CA: Corwin Press.

23. Graf, S., \& Liu, T. (2008). Interactions between students' learning styles, achievement, and behaviour in mismatched courses. National Central University Graduate Institute of Learning and Instruction. Taiwan Retrieved from

24. Alavi, S., \& Toozandehjani, H. (2017). The relationship between learning styles and students' identity styles. Open Journal of Psychiatry, 7, 90102.

25. Kaushik, P. (2017). Redefining learning: Kolb's theory of learning styles with Gardner's Multiple Intelligences. International Journal of Learning and Teaching. 9(1), 330-339.

26. Mona, O. H., \& Clas, O. (2017). Analysing teachers' operations when teaching students: what constitutes scientific theories? International Journal of Science Education, DOI: 10.1080/09500693.2017.1310407.

27. Gaikwad, H. V. (2017). Analysis of learning styles of engineering students for improving engineering education. Journal of Engineering Education Transformations, Special Issue, eISSN 2394-1707 Retrieved from http://www.journaleet.org/index.php/jeet/article/do wnload/111788/78389

http://sgraf.athabascau.ca/publications/graf_liu_kin shuk_CELDA08.pdf

28. Narayani, K. D. G. (2014). Learning style of higher secondary students in relation to their academic achievement. International Journal of Scientific and Research Publications, 4(4), Retrieved from http://www.ijsrp.org/research-paper-0414/ijsrpp2804.pdf

29. Wouter, S., Katrien, S. (2018). Power relations in educational scientific communication - A critical analysis of discourse on learning styles. Cogent Education. Retrievedfrom https://www.cogentoa.com/article/10.1080/233118 6X.2018.1429722.pdf 